\title{
Detection and Transmission of Drechslera avenae from Oat Seed
}

\author{
Marcelo A. Carmona ${ }^{1}$, Juan Zweegman ${ }^{1}$ \& Erlei M. Reis ${ }^{2}$ \\ ${ }^{1}$ Fitopatología, Facultad de Agronomía, Universidad de Buenos Aires, Av. San Martín 4453 (1417), Capital Federal, \\ Argentina, e-mail: carmonam @ agro.uba.ar; ${ }^{2}$ Faculdade de Agronomia, Medicina e Veterinaria, Universidade de \\ Passo Fundo, Cxs. Postais 566 e 567, CEP 99001-970, Passo Fundo, RS, Brasil
}

(Aceito para publicação em 10/09/2003)

Corresponding author: Marcelo Carmona

CARMONA, M., ZWEEGMAN, J. \& REIS, E.M. Detection and transmission of Drechslera avenae from oat seed. Fitopatologia Brasileira 29:319-321. 2004.

\begin{abstract}
Detection, symptoms and symptomless transmission of Drechslera avenae (teleomorph Pyrenophora avenae) from seed were investigated. The present study reported that the $D$. avenae is frequently found in oat (Avena sativa) seed in Argentina. The prevalence of the seed lot infected was 54\%. The incidence of seeds infected by $D$. avenae in the various seed lots from different regions ranged from 0 to $52 \%$ (overall mean of $7 \%$ ). Besides conidia on conidiophore and immature pseudothecia,

D. avenae produced small, spherical to pear-shape picnidia containing tiny conidia, on the seed surface. The pathogen was efficiently transmitted at a rate of $55 \%$ from seed to coleoptile tips in symptomless seedlings and at $12.5 \%$ to plumules. The importance of the infected seed and its epidemiological role are discussed.

Additional keywords: Pyrenophora avenae, Avena sativa, seed-borne pathogen, transmission.

\section{RESUMO}

Detección y transmisión de Drechslera avenae en semillas de avena El presente trabajo tuvo como objetivos detectar y cuantificar a Drechslera avenae en muestras de semillas y evaluar su transmisión hacia los coleoptiles y plúmulas de la avena (Avena sativa). Un total de trece muestras resultaron infectadas por $D$. avenae, representando un 54\% de prevalencia. Los valores máximos y mínimos de infección obtenidos fueron 0 y $52 \%$ con un promedio de $7 \%$. Sobre las semillas,

D. avenae produjo además de conidióforos, conidios y pseudotecios inmaduros, picnidios pequeños, esféricos y con forma de pera conteniendo conidios diminutos. El patógeno fue detectado en los coleoptiles, sin síntomas en las plúmulas con una eficiencia de transmisión del 55\%. La tasa de transmisión sintomática fue del $12,5 \%$. Se discuten la importancia de la semilla infectada y su papel epidemiológico.
\end{abstract}

The leaf spot of oats (Avena sativa L.) caused by the necrotrophic pathogen Drechslera avenae (Eida) Sharf (Teleomorph Pyrenophora avenae Ito \& Krib), has been recently observed throughout the Argentinean pampas region (Carmona, unpublished). In some countries, it is a very important leaf spotting disease (Fernandez Valiela, 1978). In Brazil it is the fastest spreading oat disease, mainly due to the trend towards conservation tillage and monoculture, which favours development of the disease (Blum et al., 1999). Although $D$. avenae has been detected on oat seed, there is little published information on detection, transmission and its epidemiological role. In Argentina, even though the pathogen was reported (Fernandez Valiela, 1978), there is no published research the sanitary status of the seed nor the potential role of seed borne $D$. avenae. The objectives of the present work were to detect $D$. avenae in seed samples and to evaluate the potential role of seed borne $D$. avenae, as primary inoculum for oat leaf spot epidemics.

Twenty-four seed lots of white oat were obtained from fields the provinces of Buenos Aires, Entre Ríos and La Pampa in January 2001. Samples of 400 seeds from each lot were evaluated for $D$. avenae by means of Jorgensen's (1983) deep- freezing blotter test. From each seed lot, ten conidia and ten conidiophores were measured. Minimum, maximum and average measurements were registered.

To test for patogenicity, isolation was made on potato dextrose agar (PDA) from the seed lot with the highest infection (cv. Millauquén with a D. avenae infection incidence of 52\%).

Studies of seed transmission were carried out using the same seed lot. The technique applied was the one reported in a previous work (Carmona et al., 1999) but without use of the selective agar medium developed for Cochliobolus sativus (Ito \& Kuribay) Drech. ex Dastur (Reis, 1983).

One thousand seeds were sown in multipot trays containing soil mix (soil: sand: vermiculate 1:1:1), one seed per pot, and maintained in a greenhouse at $10-30{ }^{\circ} \mathrm{C}$ (mean $15.5^{\circ} \mathrm{C}$ ). The moisture content of the soil was maintained below field capacity. At 30 days after sowing, coleoptiles of 200 symptomless seedlings were cut separately and asseptically at 1.0 to $1.5 \mathrm{~cm}$ above the soil, placed without surface disinfestation on three layers of moist filter paper in a 9-cm-diameter petri dish (ten coleoptiles/dish), and incubated for ten days as described earlier .

Transmission efficiency (TE) of D.avenae from seed to 
coleoptile was estimated from the incidence of coleoptiles colonized by $D$. avenae $(\mathrm{C})$ and the incidence of seeds infected by the pathogen $(\mathrm{S})$ : $\mathrm{TE}=\mathrm{C}(\%) / \mathrm{S}(\%) \mathrm{X} 100$. The incidence of plumules with oat leaf spot (PS) was estimated based on observations of 200 seedlings taken at random at 30 days after sowing. Plumules with symptoms were kept in high humidity for two-three days and observed for sporulation of D. avenae. Efficiency of symptomatic transmission of the pathogen (STE) was determined as STE= PS (\%) / S (\%) x 100.

The results from seed infection assays showed that a total of 13 samples were infected by $D$. avenae. The prevalence of the seed lot infected was $54 \%$. Incidence of seeds infected by $D$. avenae in the various seed lots ranged from 0 to 52 (overall mean of 7\%) (Table 1). The high seed infection and the wide prevalence of $D$. avenae from some regions of Argentina indicate that effective control measures should be investigated and applied before planting. This is the first report about the sanitary status of oat seed in Argentina indicating that considerable attention has to be paid to production and management of oat seed. No tillage farming production without rotation, and the susceptibility of the cultivar, probably would favor seed infection.

The anamorph was encountered in all assays tested. Conidiophores arising singly or in a two-four group straight or flexuous, frequently geniculate, dark, septate, 120 - $364 \mu \mathrm{m}$ $(X=234) X 8-12 \mu \mathrm{m}(X=8,5)$. The conidia were subhyaline or pale yellow, one-six septate (average four); and $32-84 \mu \mathrm{m}$ (59) X 10 - $16 \mu \mathrm{m}(11,5)$. The conidia were cylindrical with a rounded apex, and an inconspicuous scar similar to those described by Ellis (1971). Sometimes, the fungus produced black immature pseudothecia on the seeds. The pseudothecia were black, erumpent with dark spines surrounding the short beak. Although the perfect stage of $D$. avenae has been detected on seed in some countries (Kenneth, 1962; Blum et al., 1999), the mature perfect stage has not been found yet in Argentina (Fernadez Valiela, 1978). Besides conidia and immature pseudothecia, D. avenae also produced small, spherical to pearshape picnidia containing tiny conidia on the seed. This observation confirms the results recorded by other researchers (Dennis, 1933; Kenneth, 1962; Sivanesan, 1987; Mehta, 1999; Blum et al., 1999). This is the first report about the picnidial stage of D. avenae in Argentina.

The morphology of conidia, conidiophores, typical large white "tuffs" and characteristics of the culture of $D$. avenae, agree with the descriptions of this species by Drechsler (1923) and Ellis (1971) .

At ten days, all seedlings inoculated showed typical symptoms of oat leaf spot. The spots first appear as a small oval brown lesion surrounded by a red or anthocyanin margin. Later the lesion increased in size and produced necrotic foliar tissue. Reisolation confirmed the causal agent as D. avenae.

The seed transmission studies showed that at 30 days after sowing, $D$. avenae was detected in symptomless seedling coleoptile tips with a TE from seed to coleoptile of 55\%. At the same time, $6.5 \%$ of primary leaves from 200 examined, showed typical oat leaf spot symptoms. Symptoms usually appeared as minute brown spots that become larger with red or purple margins. After incubation, abundant sporulation of the fungus was registered on spots. The rate of this STE, from seed to plumule, was $12.5 \%$. Although these rates appeared low when compared to high seed infection the coleoptile infection, and abundant fructification on the leaf spots would have a considerable role under optimum environmental field conditions. There are many environmental factors that affect the transmission process of seed borne pathogens. Environmental factors such as soil moisture and temperature, rain, light are important because they favour an efficient transmission, and can incite a rapid spread and increase of the disease (Leach, 1979). Once the pathogen is established by seed transmission, it will multiply and spread repeatedly. In this case, wind blown rain is essential for the rapid spread of $D$. avenae in the field. Later, the disease will progress upward in the crop, ending by infecting the seed .Thus, the significance of seed transmission under field conditions may be higher than the one studied in the greenhouse. Similar or higher rates of transmission were reported in other species of Drechslera such as D. teres (Sacc.) Shoem. (Hamptom, 1980; Carmona et al., 1999) and D. tritici repentis (Died.) Shoem. (Schilder \& Bergstron, 1995; Carmona et al., 1998). The importance of the infected seed and its epidemiological role were confirmed in this work.

TABLE 1 - Incidence of seed borne Drechslera avenae in oat (Avena sativa) seed using the deep-freezing method (Jorgensen, 1983)

\begin{tabular}{lllr}
\hline \hline $\begin{array}{l}\text { Sample } \\
\text { number }\end{array}$ & Cultivar & Location & $\begin{array}{r}\text { \% of Seed } \\
\text { Infection }\end{array}$ \\
\hline 1 & Cristal INTA & Bragado, Buenos Aires & $13.5 \%$ \\
2 & Millauquén & Catriló, La Pampa & $52 \%$ \\
3 & Cristal INTA & Gualeguaychú Entre Ríos & $0 \%$ \\
4 & Cristal INTA & Gualeguaychú & $2.5 \%$ \\
5 & Millauquén & Gualeguaychú Entre Ríos & $1 \%$ \\
6 & Cristal INTA & Miramar, Buenos Aires & $0 \%$ \\
7 & Cristal INTA & Castex, La Pampa & $0 \%$ \\
8 & Sure Grain & Macia, Entre Ríos & $8 \%$ \\
9 & Cristal INTA & Balcarce, Buenos Aires & $0 \%$ \\
10 & Cristal INTA & Castex, La Pampa & $45.5 \%$ \\
11 & Tucana & Macia, Entre Ríos & $7 \%$ \\
12 & Bonaerense Poyé & Balcarce, Buenos Aires & $0 \%$ \\
13 & Cristal INTA & Necochea, Buenos Aires & $0 \%$ \\
14 & Cristal INTA & Miramar, Buenos Aires & $0 \%$ \\
15 & Cristal INTA & Coronel Suarez, Buenos Aires & $2 \%$ \\
16 & Millauquén & Coronel Suarez, Buenos Aires & $0 \%$ \\
17 & Pilar & Coronel Suarez, Buenos Aires & $0 \%$ \\
18 & Cristal INTA & Gualeguaychú Entre RÍos & $16 \%$ \\
19 & Cristal INTA & Gualeguaychú Entre Ríos & $10 \%$ \\
20 & Polaris & Gualeguaychú Entre Ríos & $0.5 \%$ \\
21 & Pionera & Macia, Entre Ríos & $7.5 \%$ \\
22 & Polaris & Macia, Entre Ríos & $0 \%$ \\
23 & Cristal INTA & Gualeguaychú Entre Ríos & $4.5 \%$ \\
24 & Cristal INTA & Gualeguaychú Entre Ríos & $0 \%$ \\
Prevalence & & & $54 \%$ \\
Mean & & $7 \%$ \\
\hline & & &
\end{tabular}

Data are means of 400 seeds per sample 
Seed transmission studies showed that infected seed is an important means by which $D$. avenae survives, and initiates oat leaf spot epidemics in Argentina. The infected seed is also considered to be the potential source of long distance dissemination. Since $D$. avenae was able to infect seedlings and to colonize the coleoptile, with or without symptom, early on,special attention should be paid to efficient seed control measures. Crop rotation plus an effective seed treatment can guarantee a healthy crop that avoides the introduction of the fungus. The results indicate that the $D$. avenae is frequently found in oat seed in Argentina and may be easily detected by a deep freezing blotter method. The fungus is transmitted from seeds to plumules and coleoptiles with o without symptoms expression respectively. Therefore, further field studies are needed to research, the relationship between seed infection and primary inoculum, the influence of biotic and abiotic factors in the seed transmission process, and the effects of seed treatment and level of infection tolerance.

\section{LITERATURE CITED}

BLUM, M.C., REIS, E.M. \& CASA, R.T. Ocorrência e descriçâo morfológica de Pyrenophora avenae agente etiológico da Helmintosporiose da aveia no Rio Grande do Sul. Fitopatologia Brasilera 24:513-517. 1999.

CARMONA, M.A., BARRETO, D.E. \& REIS, E.M. Detection, transmission and control of Drechslera teres in barley seed. Seed Science \& Technology 27:761- 769. 1999.

CARMONA, M., FERRAZZINI, M. \& BARRETO, D. Detection and transmission of Pyrenophora tritici-repentis in wheat seed in Argentina. Proceedings, 25th ISTA Congress. Seed Symposium .Pretoria, South Africa. 1998. p.112
DENNIS, W. G. Studies on the morphology and biology of Helminthosporium avenae. Transactions of the British Mycological Society 18:223-238. 1933.

DRECHSLER, C. Some graminicolous species of Helminthosporium. Journal Agricultural Research 24:641-739.1923.

ELLIS, M.B. Dematiaceous Hyphomycetes. Kew, CAB, 1971.

FERNANDEZ VALIELA M.V. Introducción a la Fitopatologia.Vol. III, $3^{\text {a }}$ ed., Colección Cintífica del INTA, Buenos Aires, Argentina, 1978.

HAMPTON, J.C. The role of seed borne inoculum in the epidemiology of net blotch of barley in New Zealand. New Zealand Journal Experimental Agriculture 8:297-299.1980.

JORGENSEN, J. Disease testing of barley seed and application of test results in Denmark. Seed Science \& Technology 11:615-624. 1983.

KENNETH, R. On the taxonomy, morphology and geographic origins of Pyrenophora teres Drechsler and allied species. Bulletin of the Research Council of Israel 11:55-82. 1962.

LEACH, C.M. A theoretical consideration of the epidemiology of seed-borne plant pathogens. Seed pathology Problems and progress. Proceedings, first Latin American Workshop on seed pathology, Londrina, Brazil, April, 1977, 1979.

MEHTA, Y.R. Occurrence of Drechslera spp. em aveia branca no Estado do Paraná. Summa Phytopathologica 25:96-99. 1999

REIS, E. M. Selective medium for isolating Cochliobolus sativus from soil. Plant Disease. 67:68-70. 1983.

SCHILDER, A.M. \& BERGSTRON, G.C. Seed transmission of Pyrenophora tritici-repentis, causal fungus of tan spot of wheat. European Journal of Plant Pathology 101:81-91. 1995.

SIVANESAN, A. Graminocolous species of Bipolaris, Curvularia, Drechslera, Exserohilum, and their teleomorphs. Mycological Papers 158:1-261. 1987. 